\title{
Hough Transform Görüntü İşleme Yöntemiyle Ekim Makineleri için Tohum Sayma Uygulaması ${ }^{*}$
}

\author{
Ahmet Çelik ${ }^{* * *}$, Emre Tekin ${ }^{2}$ \\ ${ }^{1}$ Kütahya Dumlupınar Üniversitesi, Mühendislik Fakültesi, Bilgisayar Mühendisliği Bölümü, Kütahya, Türkiye (ORCID: 0000-0002-6288-3182) \\ ${ }^{2}$ Kütahya Dumlupınar Üniversitesi, Mühendislik Fakültesi, Bilgisayar Mühendisliği Bölümü, Kütahya, Türkiye (ORCID: 0000-0003-2189-9265)
}

(Konferans Tarihi: 5-7 Mart 2020)

(DOI: 10.31590/ejosat.araconf33)

ATIF/REFERENCE: Çelik, A. \& Tekin, E. (2020). Hough Transform Görüntü İşleme Yöntemiyle Ekim Makineleri için Tohum Sayma Uygulaması. Avrupa Bilim ve Teknoloji Dergisi, (Özel Sayı), 260-267.

$\ddot{O} z$

Dünyadaki yaşamın devamlılı̆̆ı, meyve, sebze, tahıl ürünlerin tohumlarının korunmasına ve optimum şekilde kullanılmasına bağlıdır. Tohumların yüzeye uygun yerleşimde ne az ne de çok uygulanmaması gerekir. Tohumlar yüzeye, az uygulandığında beklenen verim elde edilemez, çok uygulandığında da yüzeyden veya ortamdan yeterince faydalanamayacağından, yine verim düşük olacaktır. Bu yüzden ekim yapılırken birim alana düşen tohum adedini belirlemek için, laboratuvar ortamında tarım makinalarının optimizasyonu yapmak gerekmektedir. Görüntü işleme birçok alanda kullanılmasına rağmen, tarım alanında da kullanılabilecek bir yöntemdir ancak bu zamana kadar yeterince kullanılmamıştır. Özellikle ürün tohum ekim makinelerinin üzerinde, birim yüzeye düşecek tohum miktarı veya birim yüzeye düşecek gübre miktarını belirlendiği değerler vardır. Bu değerlerin doğruluğu büyük önem arz etmektedir. Bu güne kadarki tarım makinelerinin tohum ve gübre ayarlarında kullanılan en yaygın yöntem, ekim makinesi tekeri döndürülerek, yüzeye düşen tohumların toplam ağırlıklarına bakılarak bulunmaktaydı. Bu yöntem hem yavaş hem de tohumların türüne göre farklılık göstermektedir. $\mathrm{Bu}$ çalışmada ise, tohum makinesinin optimizasyonu yapılırken, kamera vasıtasıyla elde edilen görüntü işlenerek yüzey üzerindeki tohum sayısı elde edilmiştir

\section{Counting Application for Planting Machines with Hough Transform Image Processing Method}

\begin{abstract}
The continuity of life in the world depends on the protection and optimum use of the seeds of fruits, vegetables, cereals. The seeds, applied neither more nor less in a suitable surface placement. As the seeds are applied less to the surface, the expected yield will not be achieved, and when it is applied too much, the yield will be low again. Therefore, in order to determine the amount of seed per unit area while planting, it is necessary to optimize the sowing machines in the laboratory environment. Although image processing is used in many fields, it is a method that can be used in agriculture, but it has not been used enough until this time. Especially, values in which the amount of seed per unit surface or the amount of fertilizer per unit surface is determined on the product seed sowing machines. The accuracy of these values is of great importance. The most common method used in the seed and fertilizer settings of the agricultural machinery to date was by turning the seeder wheel and looking at the total weight of the seeds falling on the surface. This method differs both slowly and depending on the type of seeds. In this study, while optimizing the seed machine, the image obtained by camera was processed and the number of seeds on the surface was obtained.
\end{abstract}

Keywords: Hough transform, Seed counting, Image processing, Transform gray image, Optimization

\footnotetext{
* Bu makale International Conference on Access to Recent Advances in Engineering and Digitalization (ARACONF 2020) de sunulmuştur.

** Sorumlu Yazar: Kütahya Dumlupınar Üniversitesi, Mühendislik Fakültesi, Bilgisayar Mühendisliği Bölümü, Kütahya, Türkiye, ORCID: 00000002-6288-3182, ahmet.celik@,dpu.edu.tr
} 


\section{Giriş}

Görüntü işleme çok farklı alanlarda kullanılmaktadır. Ürün yüzeylerindeki kusur tespitinde, etkin bir şekilde kullanılmaktadır(Çelik 2016). Amaç daha hızlı ve hatasız sonuç veri işlemek ve doğru sonuçlar almaktır (Çelik, 2016; Orak ve Çelik, 2016 ). İnsan faktörü bazı süreçlerin işlenmesi sırasında hata yapabilmekte veya tehlike oluşturabilmektedir. Ayrıca süreçlerin yavaş ve güvensiz olmasına neden olmaktadır(Orak ve Çelik, 2016).

Tarım alanında ürün meyvelerinin tespit edilmesi, sayılması ve sınıflandırılmasında görüntü işleme yöntemlerinden faydalanılmadır(Solak ve Altınışık, 2017; Sahu ve Dewangan, 2017). Sağlık alanında kan hücre sayımında (Sönmez vd.,2016) ya da röntgen, ultrason görüntülerinin analiz edilmesinde de kullanılmaktadır. Güvenlik alanında otoyol ya da köprü girişlerinde araç plakalarının tespit edilmesinde (HGS, OGS sistemlerinde) kullanılmaktadır (Çevik ve Çakır, (2011). Ayrıca nesne tespiti, yüz tanıma sistemlerin, özellik tanıma sistemlerinde de görüntü işleme yöntemlerinden faydalanılmaktadır.

Ürün tohumlarının ekimi yapılırken birim alana düşen tohum adedini bilerek, uygun oranda toprağın verimliliğini, iklimsel ve çevresel faktörleri göz önünde bulundurmak bereketli bir sezonu geçirmek için oldukça önemlidir. Ek olarak, Ekim işleminde birim alana düşen tohum adedinin uygun oranda olduğunda her bitkiye düşen yaşam alanındaki farklılıklar azalmaktadır. Bu durum bitkilere yeterli bir yaşam alanı sağladığından verimin arttırılabildiğini göstermiştir.

Ekim makinalarının optimizasyonu yapılarak çiftçinin arzu ettiği oranda tohum dökülmesi önemlidir. Bu nedenle ekim makinalarının yapılan ayara göre birim alana döktüğü tohum adedinin belirlenmesi gerekmektedir.

Laboratuvarlarda yapışkan bir bant düzeneği yardımıyla sıra üzeri tohum adedinin belirlenmesi yaygın olarak kullanılan bir yöntemdir. Ancak sıra üzeri tohum sayım işleminin tek tek sayılması zahmetli ve yorucu olmaktadır(Dursun ve Dursun, (2000). Tohum sayımının daha doğru ve hızlı bir şekilde yapılması gerekmektedir. Bu nedenle elektronik sayım sistemlerinin kullanılması zaruri olmuştur.

\section{Materyal ve Metot}

\subsection{Görüntü İşlemeyle Tohum Tespiti}

Tohum sayım işlemini yapılırken kamera ile elde edilen görüntüler üzerinde görüntü işleme yöntemleri kullanılmıştır. İlk başta görüntü gri görüntüye dönüştürülmüş daha sonra Bitmap yani siyah beyaz resme çevrilmiştir. Bu görüntü üzerinde içindeki nesnelerin sınırları kenarlık tespiti yapılarak belirlenmiştir(Çelik, 2016). Tohumların daha net tespit edilmesi ve görüntü üzerindeki gürültüler giderilmesi amacıyla görüntü erozyon, genişletme ve bulanıklaştırma işlemleri yapılmıştır. Bu uygulamalardan sonra Hough dönüşümü ile tohumlar sayılırken daha başarılı sonuçlar alınmıştır.

\subsection{Renkli Resmin Gri Resme Dönüştürü̈lmesi}

Görüntüler çoğu cihazdan renkli olarak elde edilmektedir. Bazı algoritmalar renkli görüntüler üzerinde çalışabilirken bazı görüntüler Gri görüntüye dönüştürülmesi gerekir. Sayım işlemi yapmadan önce ilk yapılması gereken renkli resmin siyah beyaz resme dönüştürülmesi olacaktır(Biswas vd., 2011). Gri resimler 1şı̆̆ın yoğunluğunu gösteren resimlerdir. Bu resimler bilgisayarda 8 bit formatında saklanır. Bunun anlamı her piksel 8 bit ikili kod ile saklanır. Yani $2^{8}=256$ olarak gösterilirse $0-255$ arasında değer alır. 0 siyah rengi gösterirken, 255 beyaz rengi gösterecektir. Ancak 128 değerindeki renk ise siyah ile beyaz rengin karışımı olan ara bir renk olacaktır.

24 bit renk derinliğine sahip bir görüntü içindeki her piksel 256*256*256 yanı 16.777.216 tane farklı renk tonu oluşturacaktır. Eğer Alfa kanalı da olursa görüntü 32 bit renk derinliğine sahip olacaktır. Aynı resim renkli olarak saklanmış olsaydı, her renk benzer şekilde 256 ton renk alarak $2^{8} * 2^{8} * 2^{8}=2^{24}$ yani 24 bit yer kaplar. Bu durumda aynı resim bu sefer 3 katı yer kaplamış olur.

Renkli sayısal bir görüntüyü gri bir görüntüye dönüştürme işlemi aslında RGB (Red: Kırmızı, Green:Yeşil, Blue:Mavi) renk modelinde belirtilen her bir piksele düşen gri görüntülerin ölçeklendirilmesidir. Normalde her bir pikseldeki RGB değerlerini toplayıp üçe bölerek gri resim elde edilebilir. Ancak bu gözünün farklı renkleri farklı algılama hassasiyetini tam yansıtmaz.

\subsection{Gri Görüntü Oluşturma Algoritmaları}

Gri görüntü 0 ile 255 arasında yani siyah ile beyaz arasında bir renktir. Renkli görüntüler kırmızı, yeşil ve mavi renklerin değişik oranda karışımlardan oluşmaktadır. Bu renkli resimlerin temsil ettiği ortama göre kırmızı, yeşil ya da mavi oranlar(dalga boyları) değişmektedir. Deniz görüntüsünde mavi rengin dalga boyu daha fazla, orman görüntüsünde yeşil rengin dalga boyu daha fazla, bir ateş görüntüsünde ise kırmızı rengin dalga boyu daha fazladır. Bu yüzden 3 tane algoritma kullanılmaktadır(Biswas vd., 2011). Şekil 1 'de bu algoritmaların bir görüntü üzerinde uygulanmış sonuçları görülmektedir.

\subsubsection{Ortalama(Average:Avg) Gri Değer Algoritması}

Bu yöntemde renkli görüntünün piksellerinin sahip olduğu kırmızı, yeşil ve mavi renk değerlerinin ortalaması alınarak hesaplanır. $\mathrm{Bu}$ işlemde önce kırmızı, yeşil ve mavi değerler toplanır sonra çıkan sonuç üçe bölünür. Bu işlem resmi oluşturan bütün pikseller için uygulanır(Biswas vd., 2011; Cheng, 2009). Ortalama gri değer dönüştürme formülü aşağıda gösterilmektedir.

$$
\text { GriDegeri }=(\mathrm{R}+\mathrm{G}+\mathrm{B}) / 3
$$




\subsubsection{Açıklık(Lightness:Li) Gri Değer Algoritması}

$\mathrm{Bu}$ yöntemde görüntü içindeki piksellerin renklerin ağırlıklı ortalamaları bulunarak gri değer hesaplaması yapılır. Piksel içindeki en büyük olan kırmızı, yeşil ve mavi değer ile aynı piksel içindeki en küçük kırmızı, yeşil ve mavi değer toplanarak ikiye bölünür. Aşağıda formül belirtilmiştir(Biswas vd., 2011). Açıklık gri değer dönüştürme formülü aşağıda gösterilmektedir.

$$
\text { GriDegeri }=(\max (\mathrm{R}, \mathrm{G}, \mathrm{B})+\min (\mathrm{R}, \mathrm{G}, \mathrm{B})) / 2
$$

\subsubsection{Parlaklık(Luminosity:Lu) Gri Değer Algoritması}

$\mathrm{Bu}$ metot daha karmaşık bir yöntemdir. İnsan gözleri yeşil renge daha çok hassastır. O yüzden yeşil rengin dalga boyunun daha fazla olduğu bölgeler daha parlak olur. Aşağıda bu yöntemin algoritması verilmektedir(Biswas vd., 2011). Parlaklık gri değer dönüştürme formülü aşağıda gösterilmektedir.

$$
\text { GriDegeri }=0.33 \times \mathrm{R}+0.56 \times \mathrm{G}+0.11 \times \mathrm{B}
$$

Resim Gri resme dönüştürüldüğü zaman, R,G,B değerleri hepsi aynı değeri almalıdır.

$$
\mathrm{R}=\text { GriDegeri, } \mathrm{G}=\text { GriDegeri, } \mathrm{B}=\text { GriDegeri }
$$

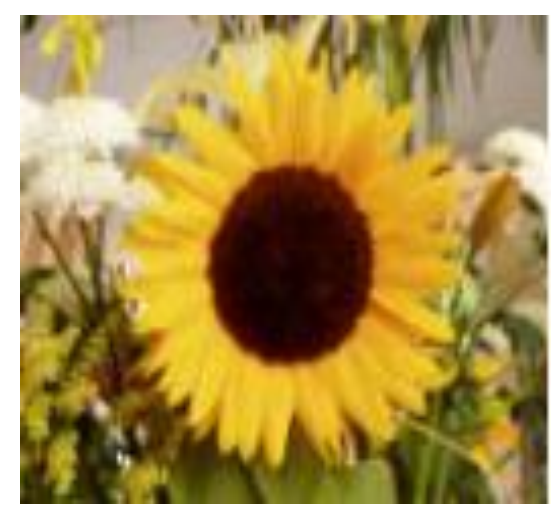

(a)

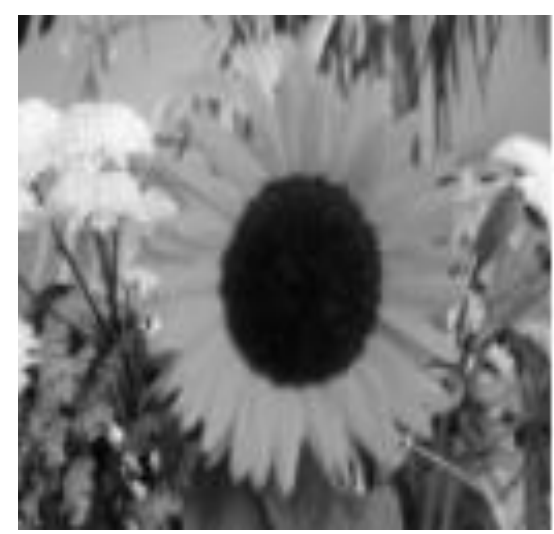

(c)

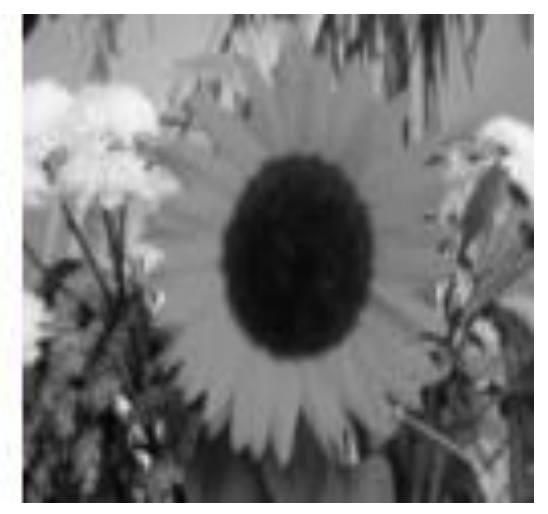

(b)

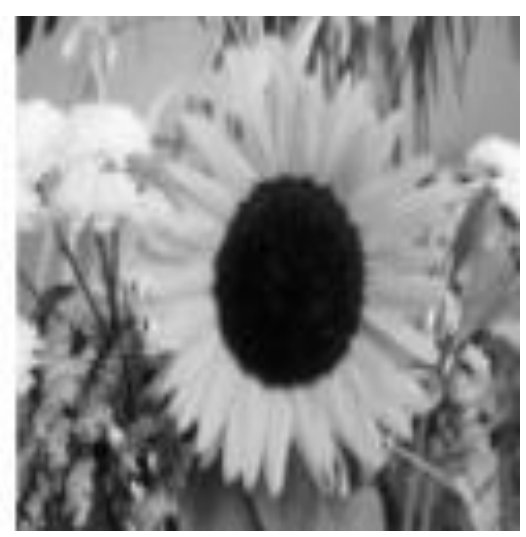

(d)

Şekil 1. a-) RGB renkli görüntü, b-)Açlkllk Gri, c-)Ortalama Gri, d-)Parlak Gri (Biswas vd., 2011).

\subsection{Bitmap Görüntü(Siyah-Beyaz)}

Bitmap görüntü 2 bit renk derinliğine sahiptir ve Gri görüntünün bir eşik değeriyle kıyaslaması sonucu elde edilir. Bitmap görüntü sadece siyah ve beyaz renkli görüntü elde edilir. Bitmap görüntüye dönüştürülürken bir eşik değeri(Threshold) kullanılır. Bu eşik değeri kullanıcı tarafından belirlenebilir ancak verilmez ise varsayılan değer 128 kabul edilebilir. Gri değeri 128 ve üstünde olan(255 e kadar) pikseller beyaz(255), 128 değerinin altında (0-127 arasında) olan pikseller ise siyah(0) olur. Bitmap görüntüye dönüştürme işlemi aşağıdaki şekilde yapılmaktadır.

$$
\begin{gathered}
\text { Eğer Gri değer } \geq \text { Threshol ise Bitmap }=255 \text { (beyaz) } \\
\text { else Bitmap }=0(\text { siyah }
\end{gathered}
$$

\subsection{Uygulama Gerçekleştirme}

Bu uygulamanın gerçekleşebilmesi için, ölçüleri belirlenmiş yüzey üzerine yeşil mercimek tohumları (örnek 30 adet) rastgele dağıtılmıştır. Daha sonra yüzeyden görüntü alınmıştır. Tohum sayım işlemini yapmadan önce arka plan çıkartılmış ve resmi gri 
görüntüye dönüştürülmüştür. Tohumların tespitinde Hough dönüşümü uygulanmıştır çünkü dairesel Hough dönüşümü tohumların şekillerine uygun görülmektedir. Ancak sadece siyah beyaz resimler ile örnek resim kümesinde yapılan denemelerde başarılı bir sonuç elde edilememiştir(Şekil 2). Tohumların yerinin tam olarak tespit edilemediği yanlış işaretlendiği durumlar olmuştur.

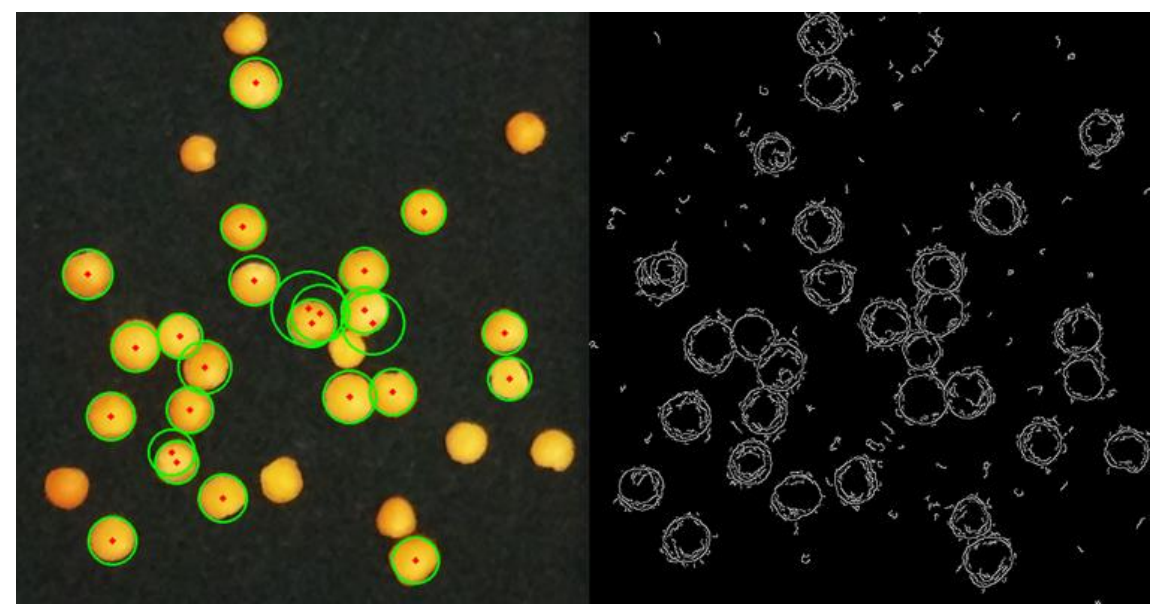

Şekil 2. Ön işlem uygulamadan Hough algoritmastyla tohum tespiti

\subsubsection{Gri Resme Genişletme(Dilation) Uygulanması}

Resim genişletme işlemi nesnenin bir gürültü ile ince bir şekilde bölünerek ayrı iki nesne gibi görünmesini engellemek için kullanılır. $3 \times 3$ boyutlarındaki sıfır ve birlerden oluşan çekirdek matris resim üzerinde gezdirilerek işlem uygulanır (Cheng, 2009). Şekil 3 üzerinde 1 piksel olarak görülen görüntü üzerinde 3x3 genişletme matrisi uygulandığında komşu piksellerinde etkilendiği görülmektedir. Genişletme uygulaması komşu piksellere merkezdeki pikselin renk değerini geçmesini ve daha büyük nesne oluşmasını sağlar.

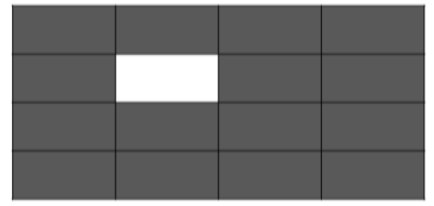

Goruntu

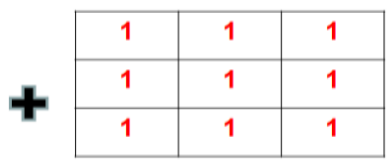

Genișletme Filtresi

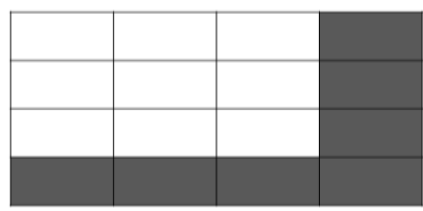

Genişletme Uygulanmış Görünto

Şekil 3. Görüntü üzerinde Genişletme İşlemi

Projede resim siyah beyaz resme dönüştürüldükten sonra görüntü genişletme yapılmıştır. Ancak istenilen sonuç yine elde edilememiştir. Şekil 4'de görüldüğü gibi bazı tohumlar çift sayılmıştır. Bu beklenilmeyen ve istenilmeyen bir durumdur. Ancak burada tohumların bazıları çift de sayılmış olsa yüksek oranda doğru tespit gerçekleştirilmiştir.

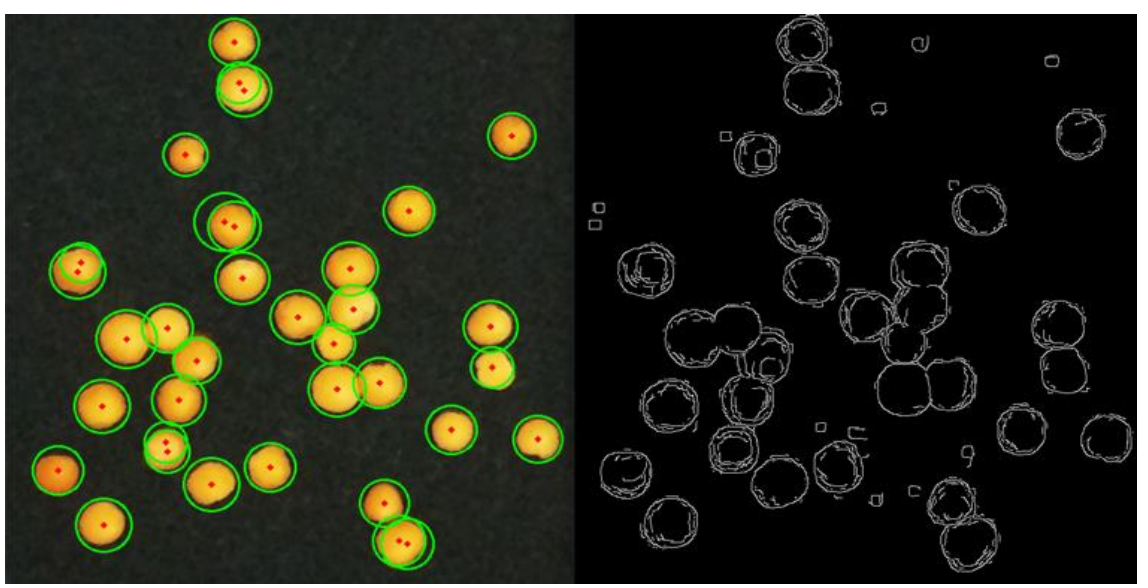

Şekil 4. Siyah beyaz resme görüntü genişletme uygulanarak tohum tespiti 


\subsubsection{Erozyon(Erosion) Uygulamast}

Erozyon yani aşındırma kenarlarda ya da görüntünün bir bölgesindeki piksellerin ortadan kaldırmak için kullanılmaktadır (Cheng, 2009). Bu işlemde de yine filtre matrisi kullanılmaktadır. Şekil 5 üzerinde, 9 piksel olarak görülen görüntü üzerinde $3 \times 3$ erozyon matrisi uygulandığında komşu piksellerinde etkilendiği görülmektedir. Erozyon uygulaması komşu piksellere etkilenir daha küçük nesne oluşmasını sağlar.

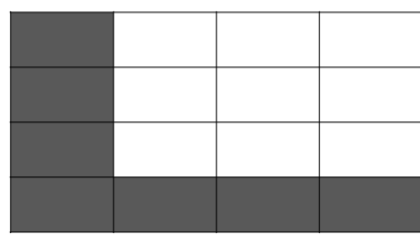

Görüntü

\begin{tabular}{|l|l|l|}
\hline 1 & 1 & 1 \\
\hline 1 & 1 & 1 \\
\hline 1 & 1 & 1 \\
\hline
\end{tabular}

Erozyon Filtresi

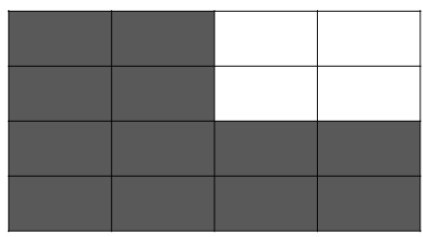

Erozyon Uygulanmış Görüntü

Şekil 5. Görüntü Üzerinde Erozyon İslemi

\subsubsection{Görüntü Bulanıklaştırma}

Bir resmin netliğinin kaybolmasının sağlandığı bulanıklaştırma, temel de belirli uzamsal bölgede komşu piksellerin ortalamasının alınması ve bu ortalama değerlerin piksellere atanması esasına dayalı bir yöntemdir. Bulanıklaştırma piksel temelli değil görüntünün bütünü ya da bir kısmı üzerinde bir filter matrisinin uygulanması temeline dayanır. En çok kullanılan Gaussian bulanıklaştırma yöntemidir(Çelik, 2016).

$$
g(x, y, t)=\frac{1}{2 \pi t^{2}} e^{-\frac{x^{2}+y^{2}}{2 t^{2}}}
$$

Burada $\mathrm{x}, \mathrm{y}$ pikselin konumlarını, $\mathrm{t}$ ise bir ölçek değişkenini belirtmektedir.

Ancak başka bulanıklaştırma filtreleri de mevcuttur. Şekil 6 üzerinde ortalama (Mean) Blur filtresi matrisi ve uygulandığında oluşacak muhtemel resim gösterilmektedir. Görüntü bulanıklaştırma gürültü etkisini ortadan kaldırmak için kullanılan bir yöntemdir(Lee ve Kim, 2014; Maraşl1 ve Öztürk, 2018).

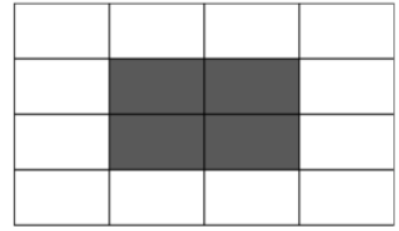

Görüntü
$1 / 9$

\begin{tabular}{|l|l|l|}
\hline 1 & 1 & 1 \\
\hline 1 & 1 & 1 \\
\hline 1 & 1 & 1 \\
\hline
\end{tabular}

Mean Blur Filtresi

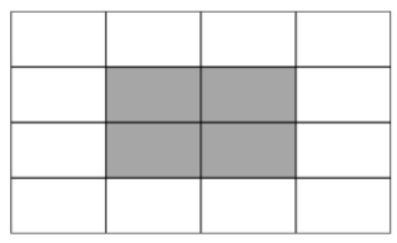

Mean Blur Filresi Uygulanmış Görüntü

Şekil 6. Görüntü üzerinde Ortalama Blur İşlemi

Görüntü genişletmeden resimde oluşan gürültüleri gidermek tohum tespitinin başarısını yükseltmek ve doğruluğunu sağlamak için fayda sağlamıştır. 


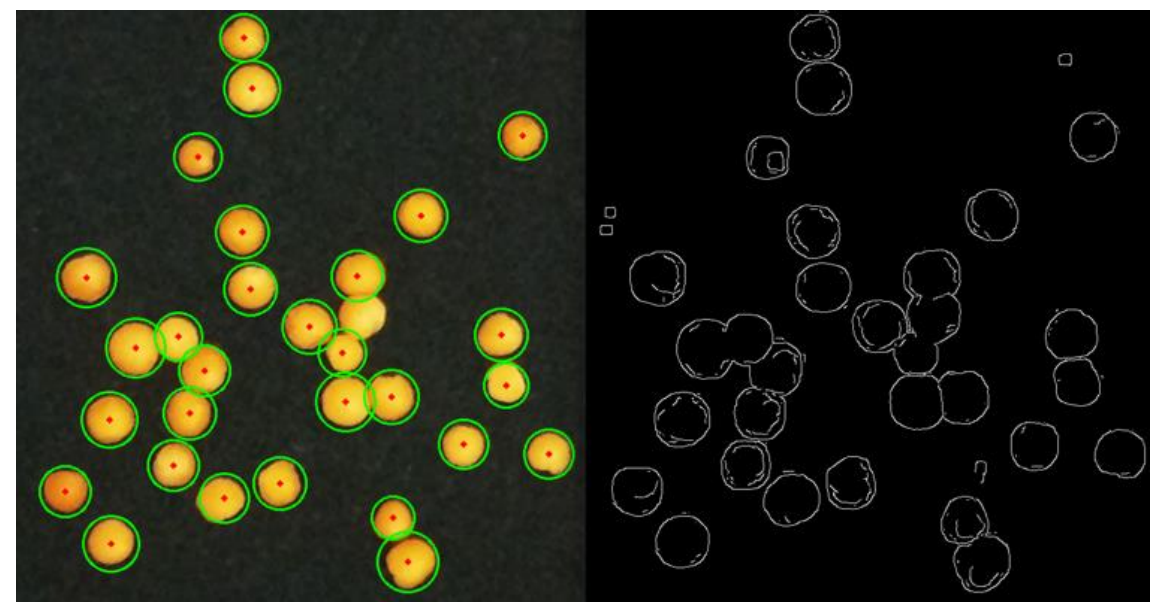

Şekil 7. Görüntü genişletilme yapılmış siyah beyaz resme, görüntü bulanıklaştırma uygulayarak tohum tespiti

\subsubsection{Görüntü Closing(Kapatma) İşlemi}

Bu işlemde, görüntü üzerinde, önce Dilation, sonra Erosion işleminin art arda yapılmasıdır. Bu işlemde görüntü içindeki nesnenin iç bölgelerinde var olan deformasyonlar ya da pikseller ortadan kalkmaktadır.

\subsubsection{Görüntü Opening(Açma) İşlemi}

$\mathrm{Bu}$ işlemde, ise görüntü üzerinde, önce Erosion, sonra Dilation işleminin peş peşe yapılmasıdır. Bu işlemde görüntü içindeki nesnenin dış bölgelerinde var olan deformasyonlar ya da pikseller ortadan kalkmaktadır.

\subsubsection{Görüntü Üzerinde Hough Dönüşümü}

Nesne tespit yöntemlerinden en önemlisi Hough dönüşümü tekniğidir. Hough Dönüşümü sayısal görüntü işlemede matematiksel olarak ifade edilebilen şekillerin varlığııın, yerinin, açılarının bulunmasında kullanılmaktadır. Yöntem 1962 yılında Paul Hough tarafından geliştirilmiştir. Yöntem daha çok herhangi bir resimdeki doğruların tespitinde kullanılmaktadır(Çelik, 2016). Ancak genel Hough dönüşümü matematiksel olarak ifade edilebilen bütün şekillerde çalışmaktadır. Doğrusal, dairesel ve genel olmak üzere üç farklı biçimiyle karşılaşılmaktadır( Fokkinga, 2011; Xiao, vd., 2010).

Sayısal görüntülerde geometrik şekil bulmanın görüntü işlemede birçok uygulama alanı bulunmaktadır. İris bulma, plaka bulma, saha üzerinde top bulma, duvar üzerinde portre bulma, masa üzerinde kalem bulma veya nesne üzerinde düzgün, düzgün olmayan kusurlu bölgeyi bulma görüntü üzerinde algoritmalar kullanılarak tespit edilebilir(Çelik,2016).

Bir kamera veya benzeri bir algılayıcı yardımı ile elde edilen görüntülerdeki şekillerin her zaman eksiksiz yer alması mümkün olmamaktadır ve şekillerdeki kopukluklar şekil tespitini zorlaştırmaktadır. Bu noktada Hough dönüşümü ile görüntünün tamamının görülebilir olmadığı durumlarda da olası şekiller tespit edilebilmektedir. Ancak doğru tespit için görüntünün eksiksiz elde edilmesi gerekmektedir. Bu projede şekil bulmada kullanılan Hough dönüşümünün dairesel şekil tespitinde kullanımı ile tohum tespiti yapılmıştır(Çelik, 2016; Ballard, 1981; Ping vd., 1996; Taşel,2012)

Hough dönüşümü temelde kenarların olası geometrik şekilleri oylaması mantığı ile çalışmaktadır. Hough dönüşümü kullanılarak şekil tespiti genel olarak aşağıdaki adımlar ile özetlenebilir(Xiao vd., 2010).

- Kaynak görüntü üzerinde kenarlar belirlenir.

- Bir eşik değeri kullanılarak görüntü ikili (siyah-beyaz) hale getirilir.

- Her kenar pikseli için noktanın üzerinde olabileceği olası geometrik şekillerin polar koordinattaki değerleri kullanılan bir matris üzerinde birer birer artırılarak her kenar pikselin olası şekilleri oylaması sağlanmış olur.

- Matris değeri en yüksek olan şekiller en çok oy alan şekiller olduklarından görüntü üzerinde bulunma veya belirgin olma olasılıkları en yüksek olmaktadır.

Bulunan şekiller isteğe bağlı olarak görüntü üzerine yazdırılabilir. Kaynak görüntüler üzerinde dairesel şekil arandığından kullanılan matrisi çemberin merkezi olan $[\mathrm{a}, \mathrm{b}]$ noktaları ve yarıçap değeri $[\mathrm{r}]$ olmak üzere üç boyuttan oluşmaktadır. Belirlenen aralıktaki yarıçap değerleri için çember merkezi çember denklemi ile bulunur(Ballard, 1981).

$$
\begin{gathered}
r^{2}=(x-a)^{2}+(y-b)^{2} \\
x=a+r \times \sin (\theta) \\
y=a+r \times \cos (\theta)
\end{gathered}
$$

Kullanılan açı değeri $0-2 \pi$ değer aralığında değiştirilerek bir noktanın, yarıçapı bilinen bir çember üzerinde yer alıp almadığı tespit edilebilmektedir. Yarıçap değerinin bilinmesi durumunda çember merkezini ifade eden $[a, b]$ değerlerinin iki boyutlu bir matrisi üzerinde tutulması yeterli olacaktır. Yarıçap değerinin bilinmemesi veya bir aralık halinde olması durumunda ise olası yarıçap değerleri bir döngü içerisinde denenerek merkez koordinatları ve yarıçap uzunluğu boyutlarına (a,b,r) karşılık gelen değerleri 
artırılarak üç boyutlu matris elde edilebilmektedir(Ballard, 1981; Ping vd., 1996; Taşel,2012). Bu çalı̧̧mada anlatılan görüntü işleme teknikleri ile istenilen forma sokulan görüntünün içerisindeki dairesel tohum taneleri, Hough dönüşümü sayesinde tespit edilerek sayılmıştır.

\section{Araştırma Sonuçları ve Tartışma}

\subsection{Görüntü İşleme Algoritmalarının Kıyaslanması}

Bu çalışmada; daha önceden tohum miktarını bulan (kilo hesabı ya da deneme yanılma) klasik yöntemleri yerine(MEB, 2015), bilgisayar destekli otomatik ve hızlı bir yöntem geliştirilmiştir. Yapılan çalışmada çeşitli görüntü işleme algoritmaları ayrı ayrı denenmiş ve sonuç olarak tohum tespitinde sadece bir yöntemle yapmak yerinde birden fazla yöntem birleştirilerek optimum sonucu ulaşmanın faydalı olacağı görülmüştür. Projede, tohum tespiti için önce ön işlem algoritması uygulamadan Hough dönüşümü uygulanmış sonra ön işlemler uygulanarak Hough dönüşümü uygulanmış en son olarak ise Dilation, Closing ve Blur işlemleri kombinasyonu uygulanmıştır.

Aşağıdaki Tablo 1'de de görüleceği üzere bazı yöntemlerde çok başarısız sonuçlar alınmıştır. Aslında başarılı gibi görünen işlemlerde, bir tohumun, birden fazla sayılarak hatalı sonuç verdiği görülmüştür.

Tablo 1. Görüntü işleme yöntemi ve başart yüzdesi tablosu

\begin{tabular}{|l|c|}
\hline \multicolumn{1}{|c|}{ İşlem } & Başarı Yüzdesi \\
\hline Siyah beyaz görüntüye dönüştürme & $83 \%$ \\
\hline Görüntü genişletme & $93 \%$ \\
\hline Görüntü erozyona uğratma & $60 \%$ \\
\hline Görüntü kapatma & $79 \%$ \\
\hline Görüntü bulanıklaştırma & $78 \%$ \\
\hline En iyi kombinasyon sonucu & $95 \%$ \\
\hline
\end{tabular}

Bu projede ulaştığımız bulgular bize tohum tespiti veya ne amaçla olursa olsun farklı görüntü işleme yöntemlerini denenerek birden çok yöntemin beraber kullanıldığında çok yüksek (\%95) başarılı sonuç alınabileceğini göstermiştir.

Örnek kümede yapılan denemelerde ise başarılı sayım yapılmış gibi duran bazı durumlarda aslında başarılı olunmadığı yanlış sayım yapıldığı anlaşılmıştır. En doğru sonucun, görüntü işleme yöntemlerinin birleştirilerek alınabileceği anlaşılmıştır.

\section{Sonuç}

Bu projede tek tek tohum sayma işleminden çok daha hızlı ve kolay bir şekilde sayım işlemi yapılabilmektedir. Bu çalışmada elde edilen sonuçlara göre, tarım makinelerinin özellikle de tohum ekme makinelerinin ayarlamaları ve optimizasyonları, test ortamında daha kısa sürede ve daha doğru olarak yapılabilecektir. Daha önceleri elle yapılan birim yüzeydeki tohum sayma işlemleri, bilgisayar destekli görüntü işleme yöntemiyle yüksek doğruluk oranıyla, kısa sürede gerçekleştirilebilecektir. İnsanların yaptıkları işlemler hem uzun süre almakta hem de hata oranları yüksek olmaktadır. Bu çalışmada, görüntü işleme yöntemlerinin yüksek doğruluk oranına sahip olduğu görülmektedir. Ayrıca görüntü işleme yöntemlerin tarım alanında kullanılmasına da örnek olacak ve büyük katkı sağlayacaktır.

\section{Kaynakça}

Çelik, A. (2016). Haddeleme İşlemi Sırasında Ray ve Profil Yüzeylerinde Oluşan Kusurların Tespit Edilmesine Yönelik Paralel İşlemci Uygulaması. Karabük Üniversitesi Fen Bilimleri Enstitüsü, Karabük, Türkiye.

Orak, İ. M. \& Çelik, A. (2016). An algorithm (COLMSTD) for detection of defects on rail and profile surfaces. International Journal of Computer Science and Information Security (IJCSIS), 14(4), 45-50

Solak, S. \& Altınışık, U. (2017 ). Görüntü işleme teknikleri ve kümeleme yöntemleri kullanılarak fındık meyvesinin tespit ve sinıflandırılması", Sakarya Üniversitesi Fen Bilimleri Enstitüsü, Sakarya Türkiye.

Sahu, D. \& Dewangan, C.( 2017). Identification and Classification of Mango Fruits Using Image Processing. International Journal of Scientific Research in Computer Science, 2(2), 203-210.

Sönmez, Y., Kutlu H. \& Avcı, E. (2016) .White Blood Cell Morphology Detection with BLOB Analysis. Tıp Teknolojileri Kongresi, Gaziantep, Türkiye.

Çevik, K. K. \& Çakır, A. (2011). Görüntü İşleme Yöntemleriyle Araç Plakalarının Tanınarak Kapı Kontrolünün Gerçekleştirilmesi. Afyon Kocatepe Üniversitesi Fen Bilimleri Dergisi, 10(1),31-38. 
Dursun, İ. G. \& Dursun, E.(2000). Ekim makinası Sıra Üzeri Tohum Dağılımının Görüntü İşleme Yöntemi ile Belirlenmesi. Tarım Bilimleri Dergisi, 6(4), 1-5.

Biswas, D., Nag, A., Ghosh, S., Pal, A., Biswas, A., Banerjee, S. \& Pal, A.(2011). Novel Gray Scale Conversion Techniques Based on Pixel Depth. Journal of Global Research in Computer Science Journal of Global Research in Computer Science, 2(6),

Cheng, X. (2009). Fast Binary Dilation/Erosion Algorithm Using Reference Points. 2009 International Conference on Networking and Digital Society, Guizhou, China,

Lee, H. \& Kim, C.( 2014). Blurred image region detection and segmentation, 2014 IEEE International Conference on Image Processing (ICIP), Paris, France.

Maraşlı, F \& Öztürk, S.(2018). Görüntü İyileştirme ve Görüntü Onarma Teknikleriyle ile Yapılmış Uygulamalar. II International Scientific and Vocational Studies Congress, Nevşehir, Türkiye.

Fokkinga, M. (2011). The Hough Transform. In: Journal of Functional Programming. Cambridge University Press, USA, 129-133.

Xiao, F., Jin, L. \& Haopeng, W. (2010). A study of image retrieval based on hough transform, 3rd IEEE Computer Science and Information Technology (ICCSIT), Chengdu, China.

Ballard, H. D. (1981). Generalizing the hough transform to detect arbitrary shapes. Elsevier B. V. Pattern Recognition, 13(2), 111-122.

Ping, F. F., Wing S. L. \& King, I. (1996). Randomized generalized hough transform for 2D grayscale object detection. Pattern Recognition, Vienna, Austria.

Taşel, F. S. (2012). Hough Dönüşümünün Dairesel Şekil Tespiti İçin CUDA Üzerinde Paralelleştirilmesi. Mühendislik ve Teknoloji Sempozyumu, Çankaya Üniversitesi, Ankara, Türkiye.

Milli Eğitim Bakanlığı(MEB) (2015). Tarım Alet ve Makineleri. Mesleki Eğitim ve Öğretim Sistemini Güçlendirme Projesi, Ankara, Türkiye. 